\title{
The Ultrastructural Basis of Steroid Production in the Y-Organ and the Mandibular Organ of the Crabs Hemigrapsus nudus (Dana) and Carcinus maenas L.*
}

\author{
Cornelia Buchholz and Dieter Adelung** \\ Institut für Meereskunde, Universität Kiel, Kiel, Bundesrepublik Deutschland
}

\begin{abstract}
Summary. The ultrastructure of the steroid producing Y-organ and the mandibular organ of the crustaceans Hemigrapsus nudus and Carcinus maenas has been studied with reference to the well investigated steroid secreting cells (SSC) of mammals. In accordance with the most important characteristic of mammalian SSC, abundant SER could be shown in the Y-organ, where it is unevenly distributed. The amount of SER seems to vary in correlation with the secretion of moulting hormone during the moult cycle. Most Y-organ cells contain a great number of mitochondria of the tubular type, another important characteristic of mammalian SSC. The ultrastructure of the mandibular organ of $C$. maenas differs considerably from that of the $\mathrm{Y}$-organ. Some SER was found, mitochondria of unusual shape and size were conspicuous. No definite conclusion as to the function of the mandibular organ is yet to be drawn.
\end{abstract}

Key words: Carcinus - Ecdysone-Hemigrapsus-Mandibular organ-Y-organ.

The only steroid hormones known thus far in arthropods are the moulting hormones (ecdysones) (Karlson et al., 1963). In vitro studies of the moulting glands of insects and crustaceans have shown that the prothoracic gland of insects and the Y-organ of crustaceans both produce $\alpha$-ecdysone (Borst et al., 1974; King et al., 1974; Romer et al., 1974; Willig and Keller, 1976; Chang and O'Connor, 1977). But in most cases $\beta$-ecdysone is considered the more effective moulting hormone (King and Sidall, 1969; Milner and Sang, 1974). Accordingly, $\alpha$-ecdysone must be converted to $\beta$-ecdysone in some other tissue in the organism of arthropods or

Send offprint requests to: Prof. Dr. D. Adelung, Institut für Meereskunde, Universität Kiel, Düsternbrooker Weg 20, D-2300 Kiel, Federal Republic of Germany

Dedicated to Prof. Dr. Peter Karlson on the occasion of his 60th birthday

* Supported by the Deutsche Forschungsgemeinschaft, grant Ad 24/4

** We wish to thank Dr. A. Owczarzak, Oregon State University, Corvallis, Oregon, for providing the facilities for our work with $H$. nudus and Thomas Gallenstein for many helpful discussions of technical problems 
alternatively $\beta$-ecdysone must be synthesized in addition to $\beta$-ecdysone somewhere else. Ultrastructural investigations should help to identify such steroid producing tissues since corresponding studies in mammals revealed a characteristic ultrastructure of steroid secreting cells (SSC) (Christensen and Gillim, 1969; Fawcett et al., 1969). Two features are considered most important, namely the mostly tubular, extraordinarily abundant, smooth endoplasmic reticulum (SER) found in almost all of the examined mammalian SSC, and the predominance of tubular mitochondria.

In crustaceans the $Y$-organ synthesizes $\alpha$-ecdysone from cholesterol (Keller and Willig, 1976; Chang and O'Connor, 1977). Yet only in some studies could abundant SER be demonstrated in these organs (Aoto et al., 1974; Chassard-Bouchaud and Hubert, 1975). Aoto et al. found in addition changes in the shape of the SER during the moulting cycle in Palaemon paucidens.

As in insects, there are indications in crustaceans that ecdysones are synthesized in additional tissues (Lachaise and Feyereisen, 1976; Willig and Keller, 1976), e.g., in certain epidermal cells of the shrimp Palaemon serratus (Chassard-Bouchaud and Hubert, 1972), which resemble in their fine structure the oenocytes of insects. Oenocytes and also ovaries of insects have been shown to be involved in the production of ecdysones (Locke, 1969; Romer et al., 1974; Hagedorn et al., 1975; Studinger and Willig, 1975). Miyawaki and Taketomi (1971) and Bazin (1976) conclude from their cytological investigations that the mandibular organ of crustaceans plays a role in the regulation of moult processes and may be responsible for the metabolism of steroid hormones. On the other hand, the findings of Aoto et al. (1974) speak against steroid production in the mandibular organ, and Byard et al. (1975) express doubts, even though their ultrastructural results could well be interpreted in favour of steroid production.

Our ultrastructural studies sought to provide further evidence for the production or conversion of steroids in the brachyuran crabs Carcinus maenas and Hemigrapsus nudus in correlation with the moulting cycle.

\section{Materials and Methods}

Carcinus maenas L. collected from the North Sea coast near Nordstrand, were kept singly in compartmented plastic boxes held in aquaria containing 2001 of well aerated sea-water at a temperature of $25^{\circ} \mathrm{C}$ and a salinity of $25 \%$. The water was filtered through a gravel and charcoal filter within a closed circulation system. Water quality was checked twice a week. A photoperiodic regimen of $L: D=8: 16$ was maintained. The crabs were fed the semi-artificial Standard Feed I of Adelung and Ponat (1977) once a day and, at the same time, checked for moults.

Hemigrapsus nudus (Dana) collected in the Yaquina Bay area of Newport, Oregon, were kept individually in perforated plastic boxes in a closed system of running sea-water from the Pacific Ocean with a salinity of $34 \%$ and a temperature of $19^{\circ} \mathrm{C}$. The photoperiodic regimen equalled that for Carcinus. Hemigrapsus was fed fresh Mytilus-meat daily. Moulting stages were determined according to Drach and Tschernigovtzeff (1967) and Adelung (1971). Y-organs and mandibular organs were removed from crabs with a carapace width of $18-22 \mathrm{~mm}$ in ice-cold seawater. The $Y$-organs were located according to Echalier's (1959) description. The mandibular organs of Carcinus maenas were easily located with the help of Le Roux's (1968) description.

Y-organs for scanning electron microscopy (SEM) were fixed in $2.5 \%$ buffered glutaraldehyde for $60-90 \mathrm{~min}$, then rinsed in Millonig's phosphate buffer. The organs were freed from most of the surrounding connective tissue before being dehydrated in an acetone series and three TF-steps (TF: 
acetone $=50: 50 ; 70: 30 ; 100 \%$ TF) and dried in a Critical Point Dryer with addition of freon 13. Some of the organs were broken up with forceps, fixed on SEM-stubs with special tape and coated with gold palladium (Au: $P d=60: 40$ ). The specimens were viewed in an ISI-MSM 2 Mini-SEM. Micrographs were taken on Polaroid P/N 55 plates.

The preparation of $Y$-organs for transmission electron microscopy (TEM) proved difficult. An acceptable preparation method for Hemigrapsus Y-organs was obtained which, however, gave very unsatisfactory results in Carcinus Y-organs. Hemigrapsus Y-organs were immersed in $2.5 \%$ glutaraldehyde in Millonig's phosphate buffer at $\mathrm{pH} 7.6$ for $1 \mathrm{~h}$, then rinsed in the $0.2 \mathrm{M}$ buffer for $4 \times 15$ min. Fixative and rinsing buffer (Millonig's) were adjusted to an osmolarity of 900 milliosmoles with the help of appropriate $\mathrm{NaCl}$-solution. Secondary fixation followed in a $2 \% \mathrm{OsO}_{4}$-solution buffered with $1.25 \% \mathrm{NaHCO}_{3}$ for $1 \mathrm{~h}$. The specimens were dehydrated in a graded series of ethanol each step being allowed $10 \mathrm{~min}$. After $2-10 \mathrm{~min}$ in $100 \%$ propylene oxide the organs were embedded in Epon 812. It proved important not to exceed $10^{\circ} \mathrm{C}$ as a preparation temperature up to the propylene oxide step.

Carcinus Y-organs were rapidly transferred to a buffered ice-cold 3\% glutaraldehyde solution to remain therein for $1 \mathrm{~h}$. They were rinsed in $0.125 \mathrm{M}$ Sörensen's phosphate buffer $(\mathrm{pH} 7.6)$ containing $0.2 \mathrm{M}$ sucrose at $4{ }^{\circ} \mathrm{C}$ and postfixed for $1 \mathrm{~h}$ in $2 \% \mathrm{OsO}_{4}$ dissolved in the buffer without sucrose. Embedding in Epon 812 was the same as in Hemigrapsus. Carcinus mandibular organs were fixed in $5 \%$ buffered glutaraldehyde for $1 \mathrm{~h}$, rinsed in $0.06 \mathrm{M}$ Sörensen's phosphate buffer containing $0.2 \mathrm{M}$ sucrose, and postfixed in $2 \% \mathrm{OsO}_{4}$ in the buffer without sucrose for $1 \mathrm{~h}$. Temperature during these steps as well as the following dehydration was maintained at $4^{\circ} \mathrm{C} ; 2 \times 15 \mathrm{~min}$ immersion in the antemedium propylene oxide followed at room temperature. The specimens were embedded in Durcupan ACM II. Thick sections $(1 \mu)$ were stained with Mallory's methylene blue. Silver and golden thin sections, were stained with uranyl acetate in $70 \%$ methanol and lead citrate (according to Reynolds, 1963), and viewed in the electron microscopes Philips EM 300, Zeiss EM 9, or RCA EMU-3H.

\section{Results}

Y-organ

The structure of the Y-organs of Carcinus maenas and Hemigrapsus nudus is very similar. Only cellular size seems to differ. The diameter of cells without processes is about $3 \mu \mathrm{m}$ larger in Hemigrapsus than in Carcinus ( $\varnothing 6-7 \mu \mathrm{m}$ ). Macroscopically the $\mathrm{Y}$-organ shows a relatively smooth surface and is quite compact. Inside an extensive system of lacunae is revealed. The cells are arranged in irregular lobules covered by a basal lamina. The lacunar system contains hemolymph with hemocytes of varying appearance (Figs. 1, 2).

The nuclei are relatively rich in chromatin and possess mostly one nucleolus. The amount of cytoplasm is generally small (Fig. 2). Long tapering cellular processes interdigitate before they end at the hemocoel and thus enhance direct access of the cells to the hemolymph. In addition individual cell surfaces are enlarged, facilitating a higher rate of exchange of substances.

Aggregations of microvesicles (Fig. 2) with an average diameter of $800 \AA$ appear mostly close to the cell's periphery; they seem to be transported in groups from cell to cell as well as into the hemolymph (Figs. 2,3). The contents of these microvesicles and their origin are uncertain. A direct connection with the SER or specific relationship with defined moulting stages were not detected.

Golgi elements are neither particularly frequent nor large in $\mathrm{Y}$-organ cells. Rough endoplasmic reticulum (RER) was not found at all, while a large number of free ribosomes could be identified. Some "lysosomal" bodies and liposomes are present. After staining with lead citrate, a number of glycogen-like rosettes appeared. Occasionally microtubules were seen. 

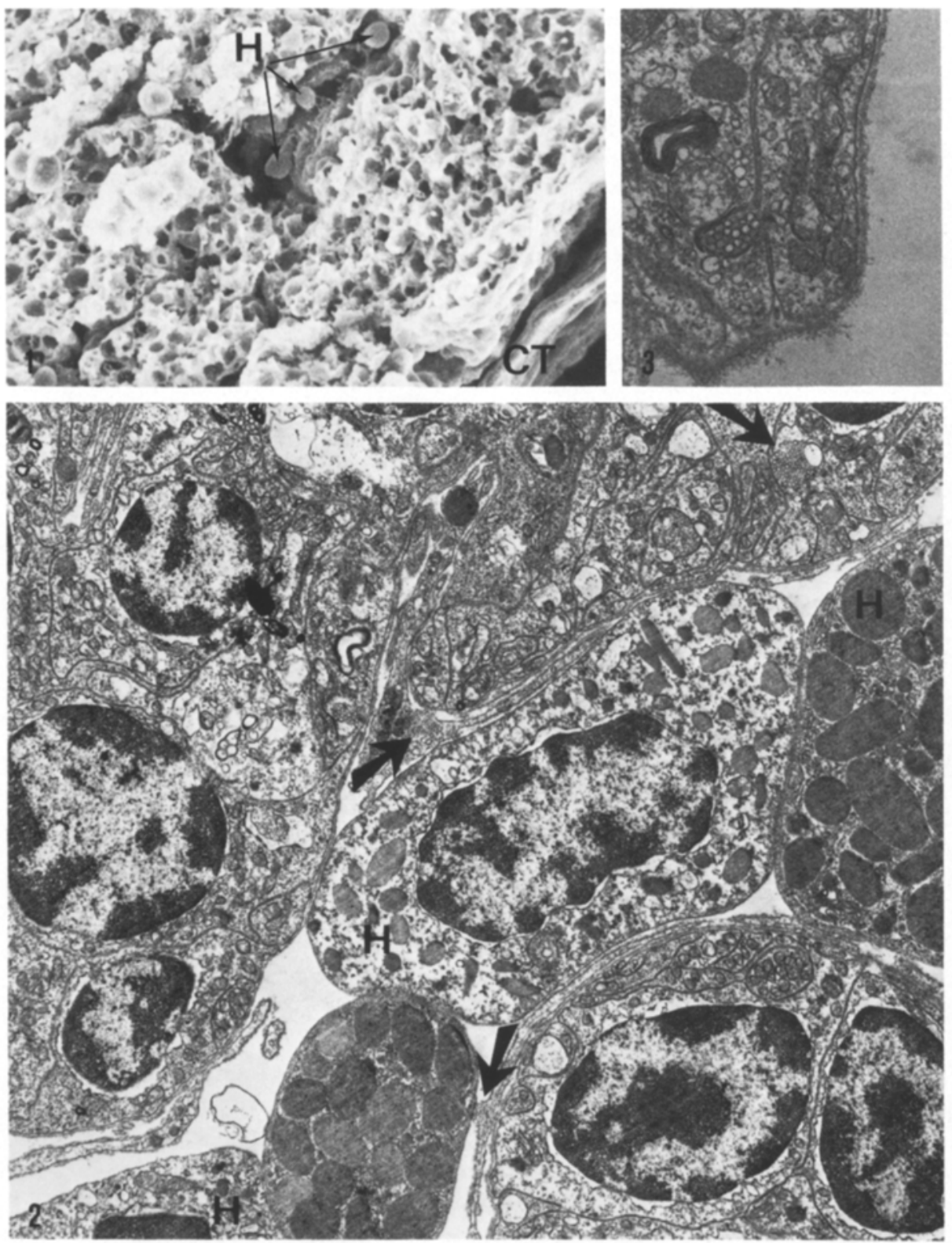

Fig. 1. Part of Y-organ of $H$. nudus. $C T$ connective tissue, which surrounds entire organ; $H$ hemocytes within sinus. $\times 700$

Fig. 2. Y-organ of $H$. nudus. Note microvesicles (arrows) presumably being released into hemolymph. $\times 6000$

Fig. 3. Y-organ of $H$. nudus. Group of microvesicles presumably being transported from cell to cell. $\times 14,000$ 

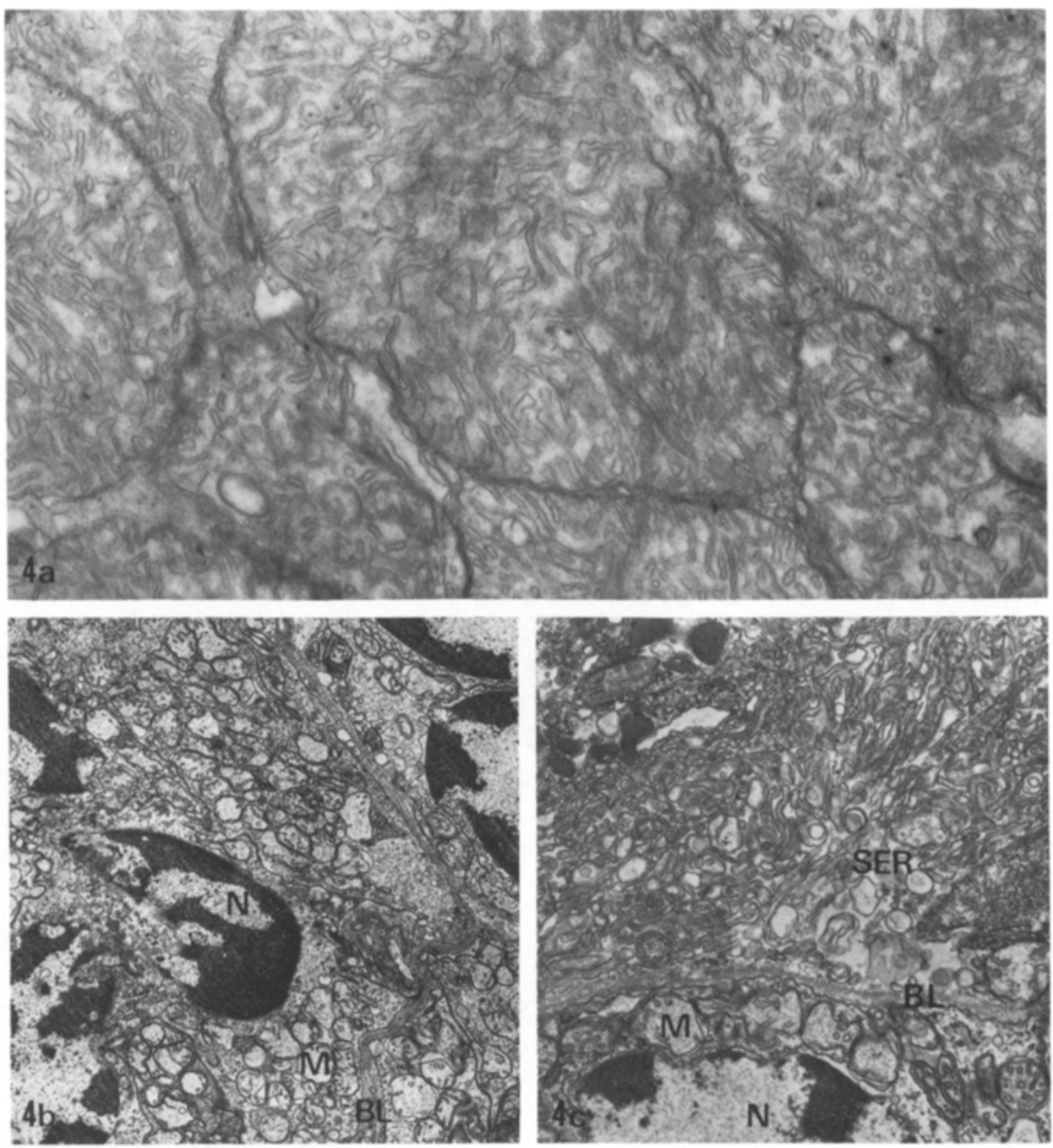

Fig. 4. Different areas of same Y-organ of $H$. nudus in moulting stage $\mathrm{D}_{1} . B L$ basal lamina; $M$ mitochondrion; $N$ nucleus; $S E R$ smooth endoplasmic reticulum. a Area of smooth endoplasmic reticulum. $\times 20,000$. b Section of cell showing mitochondria. $\times 5000$. Cells of two adjacent lobules, one with abundant SER. $\times 10,000$

In all of the examined moulting stages $\left(\mathrm{A}_{2}, \mathrm{C}_{4}, \mathrm{D}_{1}, \mathrm{D}_{2}\right)$ most cells contain, apart from large nuclei, remarkably large numbers of mitochondria, almost all of them of the tubular type. In most of the specimens examined SER is extremely sparse or absent. However, the $\mathrm{Y}$-organ of one $H$. nudus at moulting stage $\mathrm{D}_{1}$ shows about 300 sections of cells or cell processes covering an area of $20 \times 14 \mu \mathrm{m}$ filled exclusively with SER (Fig. 4a). Golgi elements cannot be clearly distinguished among the SERcisternae. Not all cells of this Y-organ contain abundant SER; many sections show the usual richness in mitochondria and no SER (Fig. 4b). SER seems to be concentrated in certain lobules of a given Y-organ. The different cell types are 


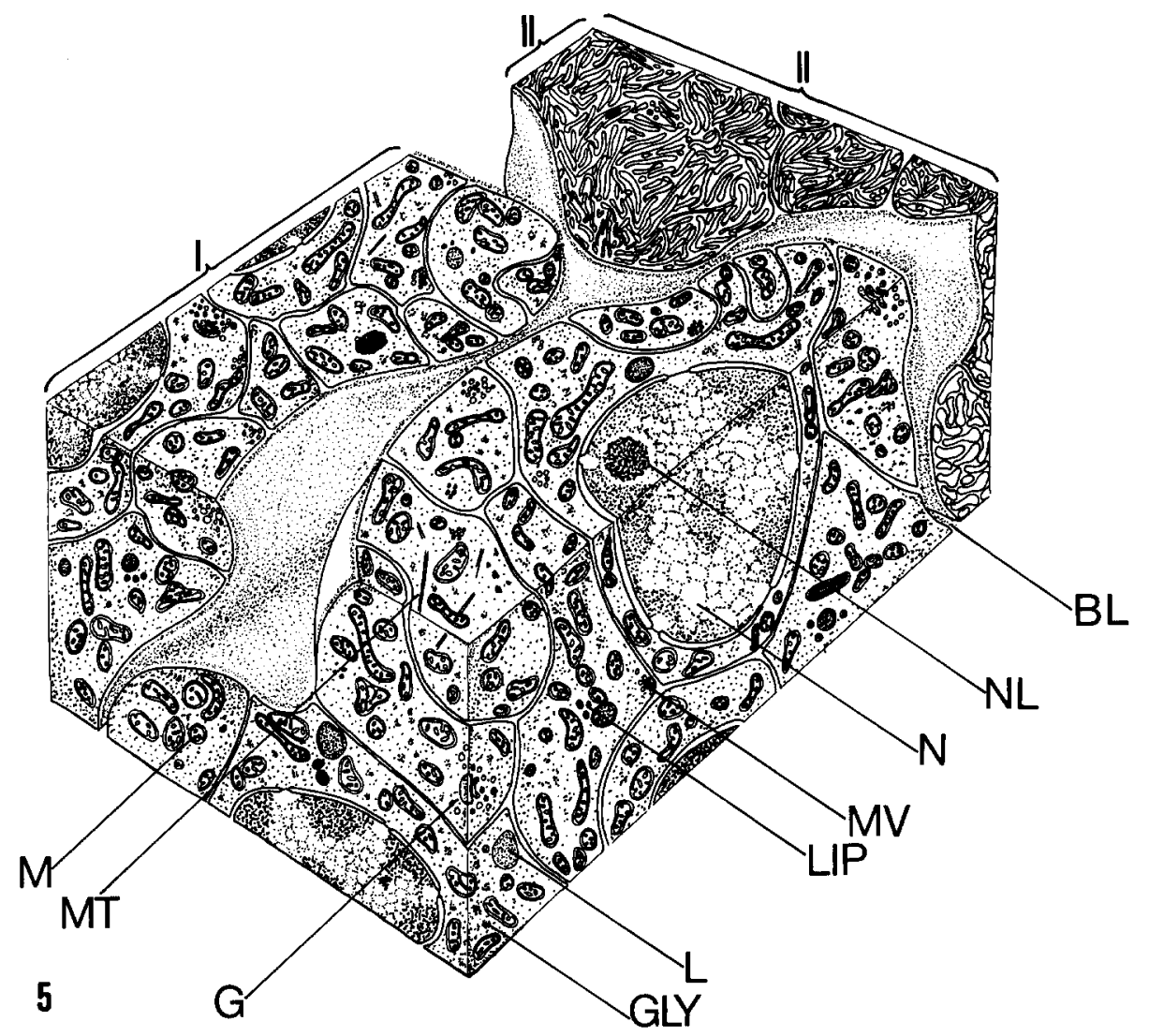

Fig. 5. Diagram of Y-organ of $H$. nudus. I lobule with most frequent cell type; $I I$ lobule with abundant smooth endoplasmic reticulum seemingly having displaced all other organelles; $B L$ basal lamina; $G$ Golgi element; $G L Y$ glycogen; $L$ lysosome; $L I P$ liposome; $M$ mitochondrion; $M T$ mictotubule; $M V$ microvesicles; $N$ nucleus; $N L$ nucleolus. Hemocytes omitted

always separated by a basal lamina (Fig. 4c) The random tubules and "tubule sheets" of the SER (cf. Christensen and Gillim, 1969) present different images depending on the plane of section.

Up to now we have not succeeded in demonstrating a corresponding abundance of SER in Y-organs of other $D_{1}$-crabs.

A diagram (Fig.5) summarizes the cytological features of the $\mathrm{Y}$-organs examined.

\section{Mandibular Organ}

The organ of only one $C$. maenas in moulting stage $\mathrm{D}_{3}$ was examined, a stage in which a very high amount of moulting hormone is released (Adelung, 1971). The mandibular organ seems less compact than the $\mathrm{Y}$-organ. Its cells are five times as 


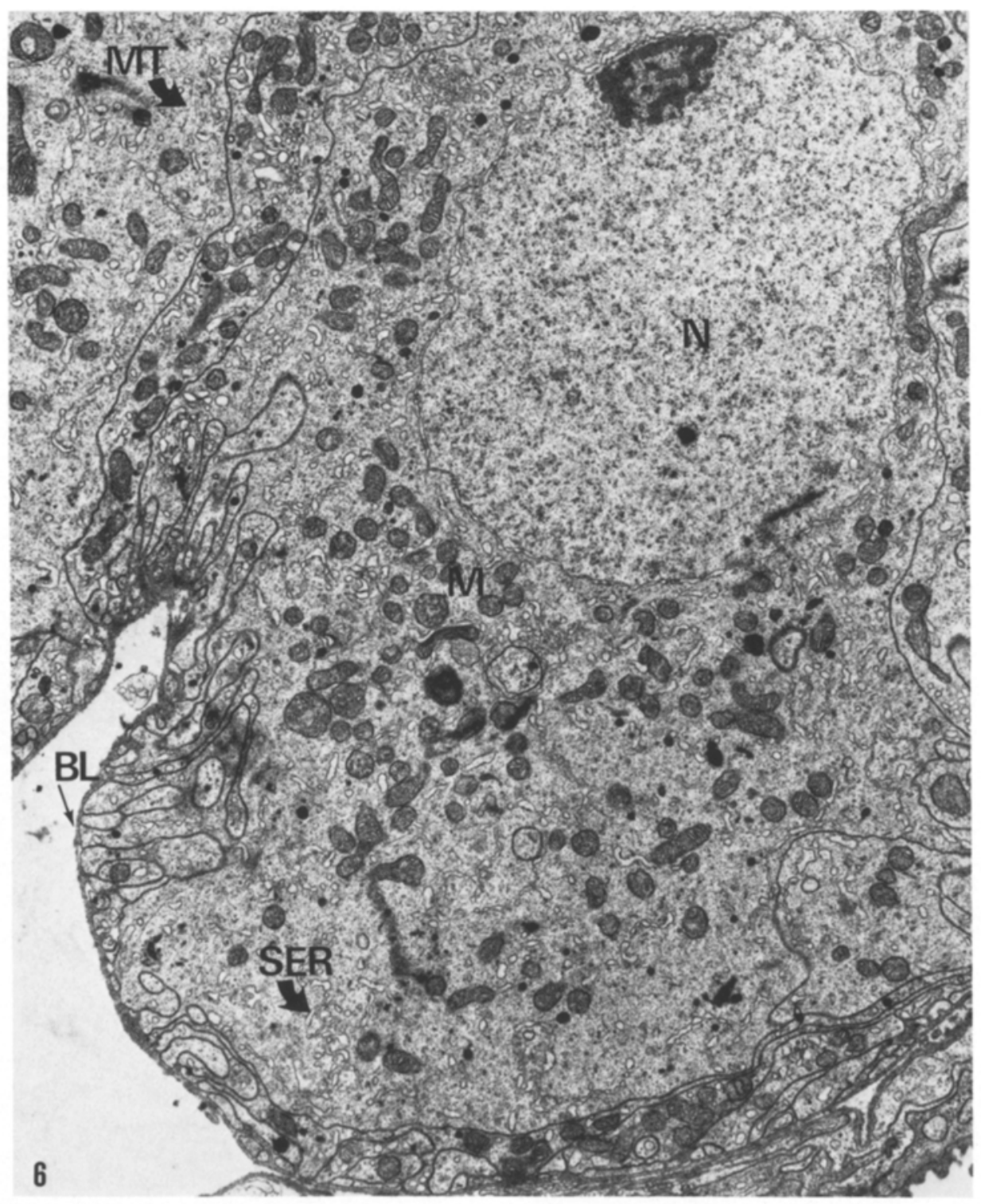

Fig. 6. Mandibular organ of $C$. maenas. $B L$ basal lamina; $M$ mitochondrion; $M T$ microtubules; $N$ nucleus; $S E R$ smooth endoplasmic reticulum. $\times 6000$

large as those of the $\mathrm{Y}$-organ, and the long axis of the nuclei is two to three times as large $(5-7 \mu \mathrm{m} / 10-13 \mu \mathrm{m})$. One or two nucleoli, but little chromatin is present. Another difference from Y-organ cells is the ample cytoplasm. Like the Y-organ, the mandibular organ consists of a number of lobules separated from the lacunar system by a basal lamina (Fig. 7). Facilitating access to blood sinuses, cellular processes are even more conspicuous than in the Y-organ (Fig. 6). A few "lysosomal" 

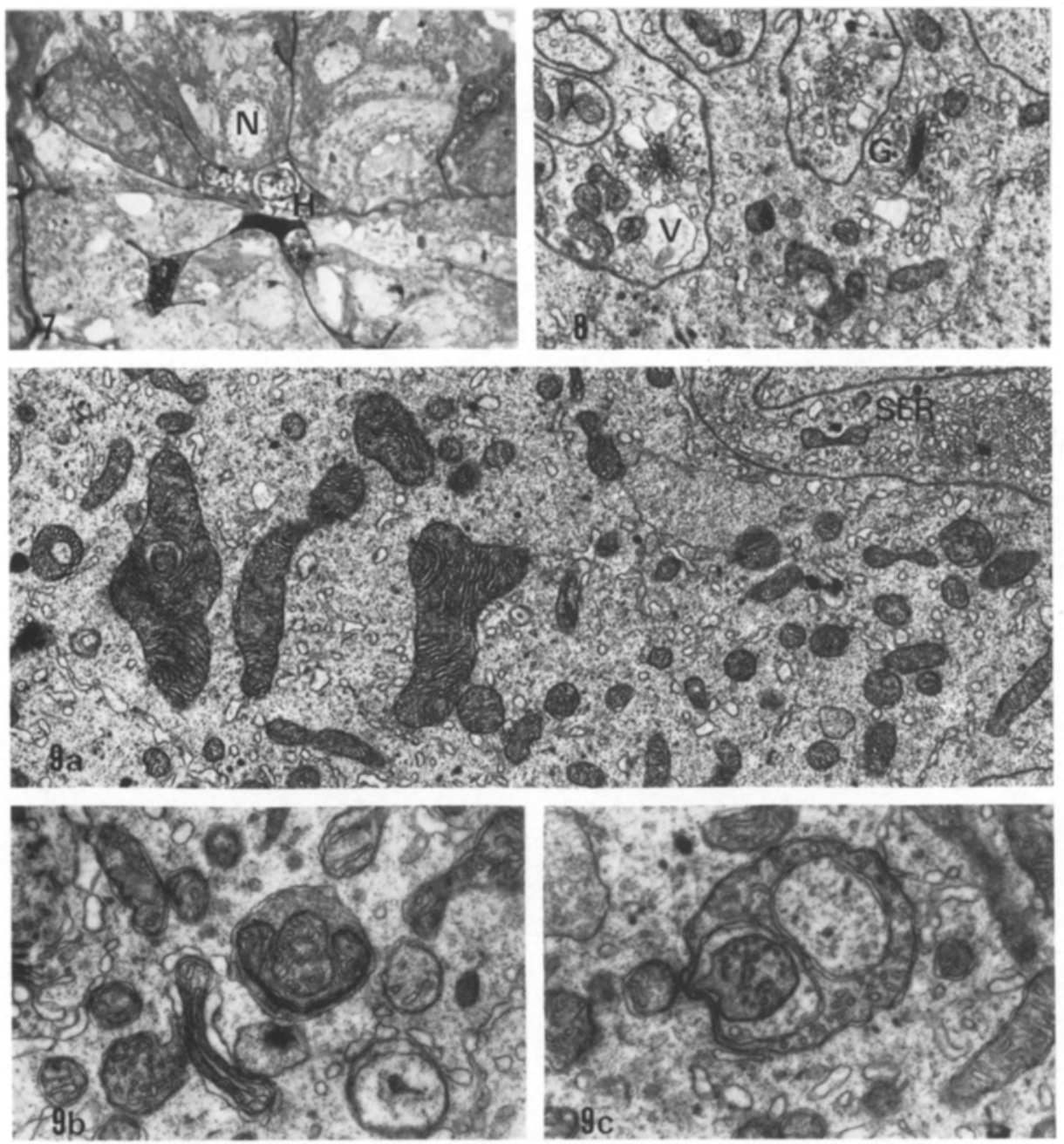

Fig. 7. Mandibular organ of $C$. maenas. Typical lumen with hemocytes. $H$ hemocytes; $N$ nucleus. $\times 700$

Fig. 8. Mandibular organ of $C$. maenas. $G$ Golgi elements, associated with $V$ vesicles. $\times 7000$

Fig. 9. Mandibular organ of $C$. maenas. Unusual mitochondria. a Macromitochondria, ringshaped profile, and SER smooth endoplasmic reticulum. $\times 7000$. b Mitochondria with longitudinal cristae. Two adjacent mitochondria enclosed in lysosome. $\times 14,000, \mathbf{c}$ Mitochondrion "within" an other mitochondrion. $\times 14,000$

and smaller liposomelike bodies are present. Aggregations of glycogen are conspicuous in some cells but not in others. Microtubules are quite common.

Free ribosomes can be identified, while stacks of RER are missing. Only some vesicles studded with ribosomes can be seen (see also: Miyawaki and Taketomi, 1971; Aoto et al., 1974). Quite a large number of very active Golgi elements are associated with larger vesicles, but are not "vesicular" themselves as Byard et al. (1975) described them for Homarus (Fig. 8). 


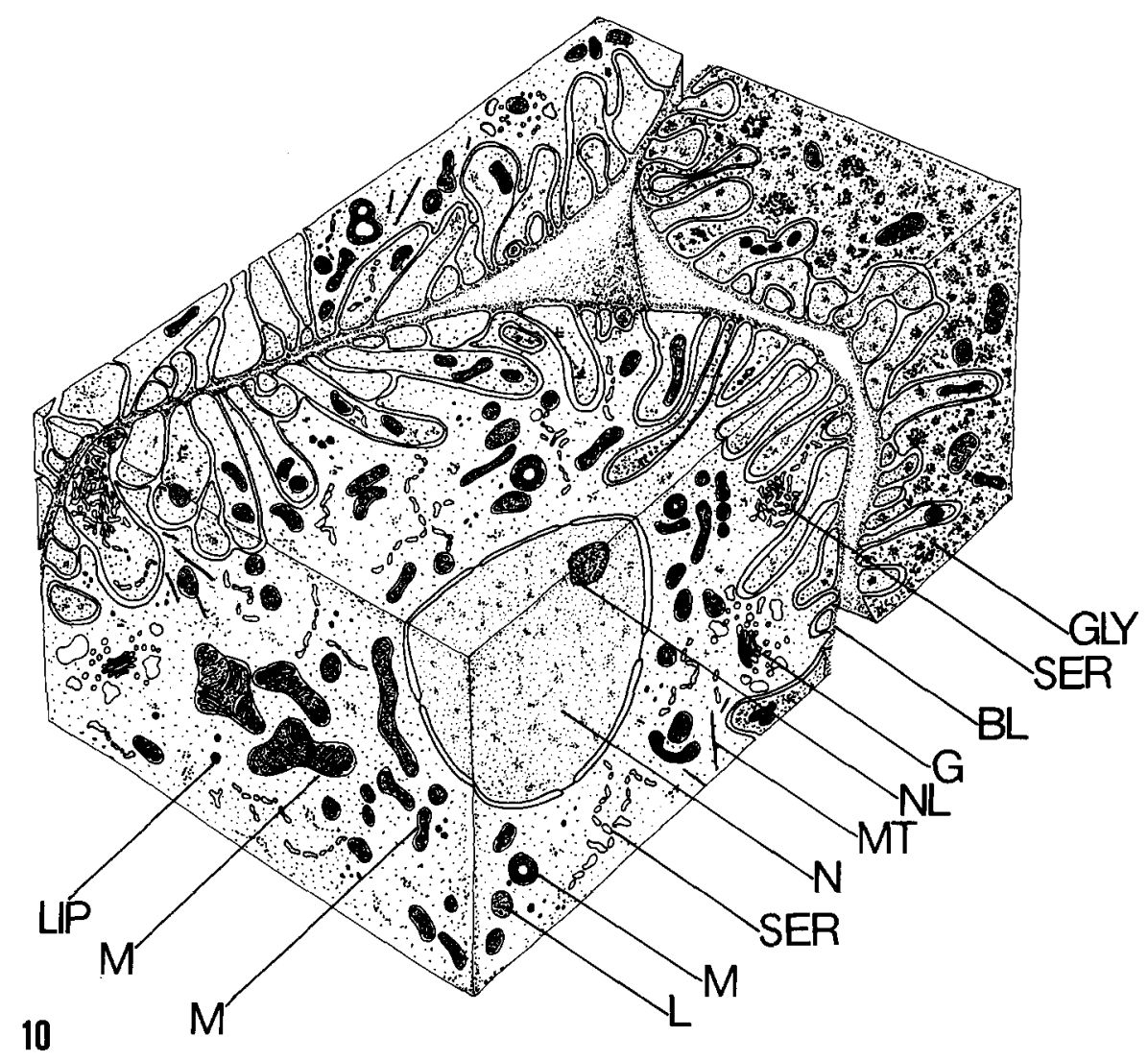

Fig. 10. Diagram of mandibular organ of $C$. maenas. Three cells bordering on same lumen, containing different amounts of glycogen. Note interdigitating cellular processes. $B L$ basal lamina; $G$ Golgi element; $G L Y$ glycogen; $L$ lysosome; $L I P$ liposome; $M$ mitochondrion; $M T$ microtubule; $N$ nucleus; $N L$ nucleolus; $S E R$ smooth endoplasmic reticulum. Hemocytes omitted

The size of the very numerous mitochondria varies greatly. Their matrices show considerably higher electron density than those of Y-organ mitochondria, and no particular inner structure predominates. Quite a number of mitochondria are of unusual shape (cf. Miyawaki and Taketomi, 1971) or exceptionally large (Figs. 9a, $b, c)$.

While Byard et al. (1975) found an extensive tubular and cisternal SER in Homarus mandibular organs, the SER in the C. maenas examined appears mostly in vesicular form. Many of the vesicles are lined up in a way to suggest that SERcisternae have fallen apart (Fig. 9a). In addition some limited areas of tubular and vesicular SER-aggregations were found.

\section{Discussion}

The most important organelles that characterize mammalian SSC, namely abundant SER and mitochondria with tubular inner structure, are without doubt 
present in Y-organ cells. This ultrastructural feature is in line with the demonstration by Chang and O'Connor (1977) and Keller and Schmid (1979) of in vitro synthesis of ecdysone by isolated $Y$-organs. It seems noteworthy that thus far, of the studied stages $\left(A_{2}-D_{2}\right)$, only the $Y$-organ in stage $D_{1}$ showed SER in amounts comparable to that in mammalian SSC. This stage corresponds to a peak in the ecdysone titer of $C$. maenas (Adelung, 1971). In addition, turnover experiments of cholesterol $-{ }^{14} \mathrm{C}$ resulted in the highest concentrations of labelled "ecdysones" in Y-organs and blood of premoult $\left(\mathrm{D}_{1}-\mathrm{D}_{2}\right) H$. nudus (Spaziani and Kater, 1973).

In the mandibular organ the conspicuous richness in mitochondria of unusual shape is accompanied by distinct SER. Even though the amount of SER does not equal that in the Y-organ, steroid production may not be completely excluded (see also: Bazin, 1976; Hinsch, 1977). Moreover Bazin noted hypertrophy of Carcinus mandibular organs after removal of the eyestalks, the source of moult inhibiting hormone. Accordingly, the mandibular organ of crustaceans might be considered a production site of $\beta$-ecdysone, either by synthesis or by conversion from $\alpha$ ecdysone, in analogy with the oenocytes in insects (Romer et al., 1974). But there are arguments against this supposition: (1) Lobsters with intact Y-organs continued to moult for up to two years after their mandibular organs were extirpated (Byard et al., 1975). (2) Keller and Schmid (1979) showed that, in vitro, mandibular organs of the macruran Orconectes limosus, in contrast to Y-organs under identical experimental conditions, at no stage produce ecdysones, while the $Y$-organs synthesize $\alpha$-ecdysone. These results are substantiated by the characteristic differences in the ultrastructure of both organs.

These facts seem to rule out the mandibular organ as a site of moult-hormone synthesis, and its designation as "moulting gland."

Byard et al. (1975) suggested that the mandibular organ is a possible analogue of the insect corpus allatum. They also provided the first ultrastructural arguments for this hypothesis. The large "whorls" of cisternal SER around microbodies they found in the mandibular organ of lobsters can be compared to the typical "allatum bodies" (King et al., 1966; Fain-Maurel et al., 1969). However, Aoto et al. (1974) found only sparse SER in Palaemon paucidens mandibular organs; Miyawaki and Taketomi (1971) observed a greater amount of SER, but no "whorls" in unmanipulated control animals. We found distinct, but relatively small SER aggregations in the mandibular organ of $C$. maenas and no SER-whorls. It may be important that Byard et al. (1975) and also Miyawaki and Taketomi (1971) found the SER changing according to the moulting cycle. The concept that it functions as a conversion site for steroids cannot be excluded.

Neither in mammals nor in insects or crustaceans has it been possible to ascertain the mode of transport and release of steroid hormones into the circulation. The following possibilities may be discussed: the extensive surface enlargement of SSC of the Y-organ, the mandibular organ, and the prothoracic gland supports the most common view of simple diffusion of steroid molecules through plasma membranes. The presence of microvesicles in steroid producing tissues may be interpreted in terms of "reversed micropinocytosis" (Scharrer, 1964; Blaszek et al., 1975). In crustacean Y-organs, Chassard-Bouchaud and Hubert (1975) found microvesicles of about the same size we observed. They regard them as derived from the SER and filled with moult hormone. Autoradiography will be required to determine whether the microvesicles contain ecdysones. 


\section{References}

Adelung, D.: Untersuchungen zur Häutungsphysiologie der dekapoden Krebse am Beispiel der Strandkrabbe Carcinus maenas. Helg. Wiss. Meeresunters. 22, 66-119 (1971)

Adelung, D., Ponat, A.: Studies to establish an optimal diet for the decapod crab Carcinus maenas under culture conditions. Marine Biology 44, 287-292 (1977)

Aoto, T., Kamiguchi, Y., Hisano, S.: Histological and ultrastructural studies on the Y-organ of the fresh-water prawn Palaemon paucidens, with special reference to their relation with the molting cycle. J. Fac. Sci., Hokkaido U., Serie VI Zool. 19, (2), 295-308 (1974)

Bazin, F.: Mise en évidence des caractères cytologiques des glandes stéroidogènes dans les glandes mandibulaires et les glandes Y du Crabe Carcinus maenas L. normal et épédonculé. C. R. Acad. Sci. Paris, Ser. D, 282, 739-741 (1976)

Blaszek, I.: Ultrastructural study of the prothoracic glands of Galleria mellonella L. in the penultimate, last larval, and pupal stages. Cell Tissue Res. 158, 269-280 (1975)

Borst, D.W., Engelmann, F.: In vitro secretion of $\alpha$-ecdysone by prothoracic glands of a hemimetabolous insect, Leucophaea maderae. J. Exp. Zool. 189, 413-419 (1974)

Byard, E.H., Shivers, R.R., Aiken, D.E.: The mandibular organ of the lobster, Homarus americanus. Cell Tissue Res. 162, 13-22 (1975)

Chang, E.S., O'Connor, J.D.: Secretion of $\alpha$-ecdysone by crab Y-organs in vitro. Proc. Natl. Acad. Sci. USA, 74, 615-618 (1977)

Chassard-Bouchaud, C., Hubert, M.: Présence de réticulum endoplasmique agranulaire et tubulaire dans l'épiderme de Palaemon serratus (Pennant) Crustacé Décapode. C.R. Acad. Sci., Ser. D, 275, 2905-2907 (1972)

Chassard-Bouchaud, C., Hubert, M.: Sur l'existence de vésicules de réticulum endoplasmique lisse dans l'organe Y de Carcinus maenas L. C.R. Acad. Sci., Ser. D, 281, 707-709 (1975)

Christensen, A.K., Gillim, S.W.: The correlation of fine structure and function in steroid secreting cells with emphasis on those of the gonads. The Gonads. K.W. Kerns, ed.,415-488, New York: AppletonCentury Crofts (1969)

Drach, P., Tschernigovtzeff, C.: Sur la méthode de détermination des stades d'intermue et son application générale aux crustacés. Vie milieu 18, (3A), 595-607 (1967)

Echalier, G.: L'organe $Y$ et le déterminisme de la croissance et de la mue chez Carcinus maenas (L.) Crustacé Décapode. Ann. Sci. Nat., Ser. 12 Zool. 1, 1-59 (1959)

Fain-Maurel, M.A., Cassier, P.: Etude infrastructurale des corpora allata de Locusta migratoria migratorioides (Rand F.), phase solitaire, au cours de la maturation sexuelle et des cycles ovariens. C.R. Acad. Sci. Ser. D, 268, 2721-2723 (1969)

Fawcett, D.W., Long, J.A., Jones, A.L.: The ultrastructure of endocrine glands. Recent Progress in Hormone Research 25, 315-380 (1969)

Hagedorn, H.H., O'Connor, J.D., Fuchs, M., Sage, B.: The ovary as a source of $\alpha$-ecdysone in an adult mosquito. Proc. Natl. Acad. Sci. USA, 72, 3255-3259 (1975)

Hinsch, G.W.: Fine structural changes in the mandibular gland of the male spider crab, Libinia emarginata L. following eyestalk ablation. J. Morphol. 154, 307-316 (1977)

Karlson, P., Hoffmeister, H., Hoppe, W., Huber, R.: Zur Chemie des Ecdysons. Liebig's Ann. 662, 1-20 (1963)

Keller, R., Willig, A.: Experimental evidence of the molt controlling function of the Y-organ of a macruran decapod, Orconectes limosus. J. Comp. Physiol. B 108, 271-278 (1976)

Keller, R., Schmid, E.: In vitro secretion of ecdysteroids by $\mathrm{Y}$-organs and lack of secretion by mandibular organs of the crayfish following molt induction. J. Comp. Physiol. B 130, 347-353(1979)

King, D.S., Sidall, J.B.: Conversion of $\alpha$-ecdysone to $\beta$-ecdysone by crustaceans and insects. Nature 221, 955-956 (1969)

King, D.S., Bollenbacher, W.E., Borst, D.W., Vedekis, W.V., O'Connor, J.D., Ittycheriah, P.I., Gilbert, L.I.: The secretion of $\alpha$-ecdysone by the prothoracic glands of Manduca sexta in vitro. Proc. Natl. Acad. Sci., USA 71, 793-796 (1974)

King, R.C., Aggarwal, S.K., Bodenstein, D.: The comparative submicroscopic cytology of the corpus allatum - corpus cardiacum complex of wild type and fes adult female Drosophila melanogaster. J. Exp. Zool. 161, 151-176 (1966)

Lachaise, F., Feyereisen, R.: Metabolisme de l'ecdysone par divers organes de Carcinus maenas L. incubés in vitro. C.R. Acad. Sci., Ser. D, 283, 1445-1448 (1976)

Le Roux, A.: Description d'organes mandibulaires nouveaux chez les Crustacés Décapodes. C.R. Acad. Sci., Ser. D, 266, 1414-1417 (1968) 
Locke, M.: The ultrastructure of the oenocytes in the molt/intermolt cycle of an insect. Tissue and Cell 1, 103-154 (1969)

Milner, A., Sang, J.: Relative activities of $\alpha$-ecdysone and $\beta$-ecdysone for the differentiation in vitro of Drosophila melanogaster imaginal discs. Cell 3, 141 (1974)

Miyawaki, M., Taketomi, Y.: Changes of Y-gland cell structure of the crayfish, Procambarus clarkii, during the molt cycle and in some experimental conditions. Kumamotu J. Sc. Biol 10, 55-67 (1971)

Reynolds, E.S.: The use of lead citrate at high $\mathrm{pH}$ as an electron-opaque stain in electron microscopy. J. Cell Biol. 17, 208 (1963)

Romer, F., Emmerich, H., Nowock, J.: Biosynthesis of ecdysones in isolated prothoracic glands and oenocytes of Tenebrio molitor in vitro. J. Insect. Physiol. 20, 1975-1987 (1974)

Scharrer, B.: The fine structure of blattarian prothoracic glands. Z. Zellforsch. 64, 301-326 (1964)

Spaziani, E., Kater, S.B.: Uptake and turnover of cholesterol- ${ }^{14} \mathrm{C}$ in Y-organs of the crab Hemigrapsus nudus as a function of the molt cycle. Gen. Comp. Endocrinol. 20, 534-549 (1973)

Studinger, G., Willig, A.: Biosynthesis of $\alpha$ - and $\beta$-ecdysone in isolated abdomens of larvae of $M$ usca domestica. J. Insect. Physiol. 21, 1793 (1975)

Willig, A., Keller, R.: Biosynthesis of $\alpha$-and $\beta$-ecdysone by the crayfish Orconectes limosus in vivo and by its $Y$-organs in vitro. Experientia 37, 936-937 (1976)

Accepted November 6, 1979 